\title{
Effect of a Bio-Waste Based on Seed Cotton on Some Properties of Soils Under Market Gardening in the Department of Korhogo in the North of Côte d'Ivoire
}

\author{
Alui Konan Alphonse ${ }^{1 *}$, Fofana Inza Jésus ${ }^{2}$, Akotto Odi Faustin ${ }^{3}$ and Yao-Kouamé Albert $^{3}$
}

${ }^{1}$ Department of Geosciences, UFR of Biological Sciences, University Peleforo Gon Coulibaly Korhogo, Korhogo, Côte d'Ivoire

${ }^{2}$ Department of Genetic Biochemistry, UFR of Biological Sciences, University Peleforo Gon Coulibaly Korhogo, Korhogo, Côte d'Ivoire

${ }^{3}$ Department of Soil Sciences, UFR Earth Sciences and Mineral Resources, University Felix Houphouët-Boigny, Abidjan, Côte d'Ivoire

DOI: $10.36347 /$ sjavs.2020.v07i03.003

| Received: 22.02.2020 | Accepted: 01.03.2020 | Published: 21.03 .2020

*Corresponding author: Alui Konan Alphonse

Abstract

Original Research Article

Depletion of soils and climate change are currently reducing crop yields in West Africa. As a solution, soil improvement based on organic waste products is often considered. The experimental device used for this experiment is a File block with three repetitions which includes five treatments, namely T0: control plot, T1: treatment of bio-waste after one month of degradation, T2: treatment of bio-waste after three months of degradation, T3: NPK treatment drawn 15-15-15 (fertilizer for cotton), frequently used by populations in the fertilization of vegetable crops and T4: biofertilizer from the local market. The lettuce seedlings of the verdana variety (Lactuca sativa) from a nursery, were sown on the different treatments, then followed for 45 days. Biowaste samples at one month and three months of degradation, as well as soil samples taken in a depth of 0 to $20 \mathrm{~cm}$, after the experiment were used for various laboratory analyzes. The results obtained indicate that the $\mathrm{T} 2$ treatment had a better carbon level $(\mathrm{C}=2.04 \mathrm{~g} / \mathrm{kg})$ compared to the other treatments. Furthermore, the study revealed C / N ratios varying between 6.05 and 9.13 for treatments based on bio-waste compared to the control $(\mathrm{C} / \mathrm{N}=2)$. The lettuce yields obtained after the various applications of bio-waste have significantly improved compared to other treatments (control, biofertilizer and chemical fertilizer). Thus for $\mathrm{T} 0$ the yield obtained is $0.23 \mathrm{~T} /$ ha against $1.39 \mathrm{~T} /$ ha for $\mathrm{T} 1,0.57 \mathrm{~T} / \mathrm{ha}$ for $\mathrm{T} 2 ; 0.4 \mathrm{~T} / \mathrm{ha}$ for $\mathrm{T} 3$ and $0.23 \mathrm{~T} / \mathrm{ha}$ for $\mathrm{T} 4$. Compared to the technical data sheet for this variety of lettuce, the $\mathrm{T} 1$ treatment has a better yield compared to others.

Keywords: Soils, organic residual products, amendment, Fertilization, Côte d'Ivoire.

Copyright @ 2020: This is an open-access article distributed under the terms of the Creative Commons Attribution license which permits unrestricted use, distribution, and reproduction in any medium for non-commercial use (NonCommercial, or CC-BY-NC) provided the original author and source are credited.

\section{INTRODUCTION}

Agriculture constitutes the pillar of the African economy and accounts for approximately $20 \%$ of the continent's GDP, $60 \%$ of its workforce, $20 \%$ of all its exports and constitutes the main source of income for rural populations. . In the dry tropical zone, the cultivation of land leads to a rapid reduction in the stock of organic matter and the appearance of nitrogen, phosphorus and various elements deficiencies [1]. The major constraint of agricultural production in Africa is the low level of soil fertility [2]. The problem of declining soil fertility is a concern both for farmers facing the high cost of inputs and for researchers whose research aims to maintain or restore the fertility of degraded soils for intensification of agricultural production [2]. One of the strategies for improving soil fertility, especially degraded soils, is the use of compost [3].
Bio-waste from cotton production can find its place in two new recovery sectors: agricultural and revegetation or restoration of the natural environment (renaturation). These channels would allow the recovery of large volumes of bio-waste and their recycling, allowing a considerable supply of materials for plant nutrition. In addition, the necessary agroecological transition in agriculture requires an increase in biological diversity and the intensification of ecological interactions between the biophysical components of ecosystems which promote fertility, productivity and resilience in the face of external disturbances [4]. In this context, the contribution of organic matter to the soil level in a highly degraded system appears promising. Thus, bio-waste based on seed cotton could lead to increased functional resilience to climate change $[5,6]$. To understand the mechanisms, it is important to determine the effect of 
bio-waste based on seed cotton on the physical and chemical characteristics of some degraded soils under market gardening in the north of Côte d'Ivoire, still little studied. Indeed, the use of composts produced with organic waste can promote a wide range of ecosystem services, including those associated with underground biotic interactions such as $\mathrm{C}$ sequestration [7] and improve soil properties. They improve soil structure, increase the water and nutrient retention capacity of the soil, stimulate microbial activity and increase crop yields. In addition, organic fertilizer sources with a C / $\mathrm{N}$ ratio below 20 contain a high concentration of nutrients [8] and have nitrogen immobilization potentials. Agricultural recycling of this organic waste product will therefore, in the long term, improve organic status, liming and fertilizing the soil.

The objective of this study is to know the effects of bio-waste of vegetable origin on lettuce culture. It is specifically a question of evaluating the effect of biowaste based on seed cotton on the physical and chemical properties of soils under vegetable crops and on the yield of lettuce.

\section{MATERIAL AND METHODS}

\section{Physiographic and climatic of the study area}

The area of interest is the department of Korhogo, located in the North of Côte d'Ivoire, between longitudes $5^{\circ} 15$ and $6^{\circ} 20$ West and latitudes $8^{\circ} 30$ and $10^{\circ} 25$ North [9]. The relief of the area is monotonous with altitudes varying on average between 300 and 400 $\mathrm{m}$. There are granite inselbergs in the landscape, sometimes reaching an altitude of more than $500 \mathrm{~m}$. The Korhogo region is made up of lateritic plateaus varying in height from 0 to $3 \mathrm{~m}$, witnesses of an ancient peneplain. These plateaus are affected by a very slight and regular slope towards the Bandama river. The humid tropical climate of the region results in an average annual precipitation fluctuating around 1200 $\mathrm{mm}$.

\section{Plant Material and Fertilizers}

The bio-waste based on seed cotton at 1 month and 3 months of decomposition was used during this experiment. We have also used as an example of market gardening lettuce (Latuca sativa) plant widely consumed by the people of Korhogo. To do this, the variety verdana (Batavia) was selected. The seeds from this hybrid variety constitute a homogeneous first generation. Verdana lettuce has good heat resistance. Its large-caliber leaves are very tasty. It is a 50-60 day variety, disease resistant with $90 \%$ germination rate (Figure-1). We also used NPK (15-15-15) and a fertilizer from the local market, used by women for the fertilization of vegetable crops.

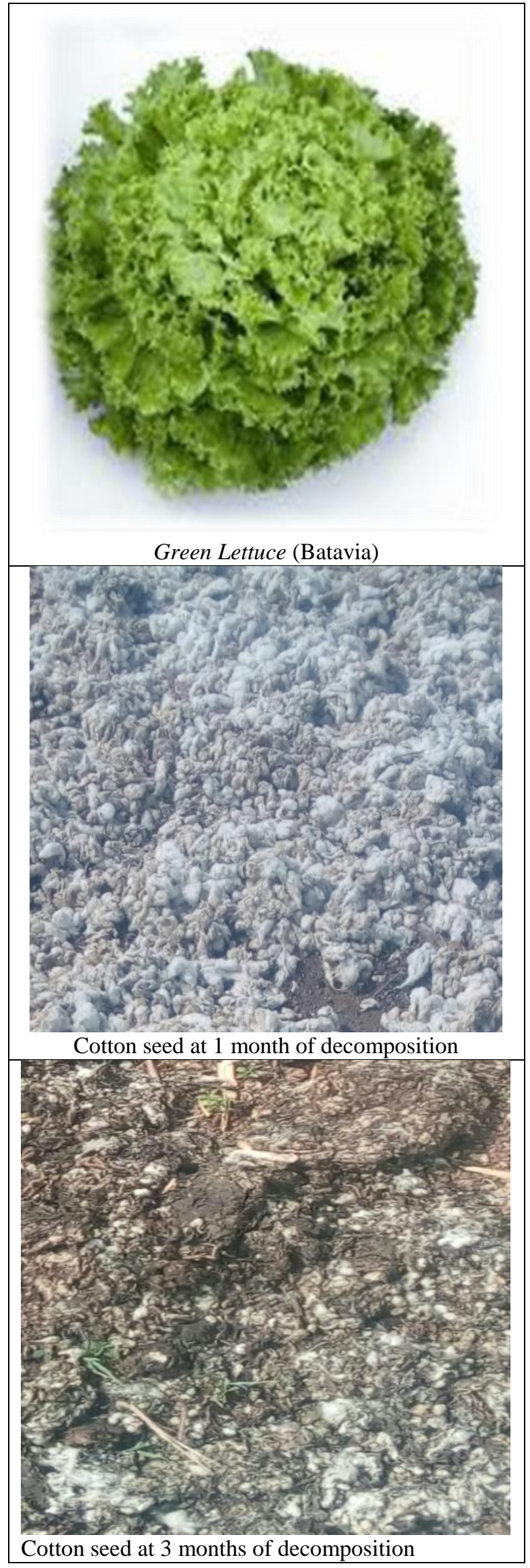

Fig-1: Lettuce and bio-waste used 


\section{METHODS}

\section{Experimental Apparatus}

The essay was arranged in a File block with 3 repetitions. The elementary plot consisted of a board 3.5 $\mathrm{m}$ long and $1.5 \mathrm{~m}$ wide $\left(5.25 \mathrm{~m}^{2}\right)$. The plants were transplanted onto the board in double lines at the rate of $0.5 \mathrm{~m}$ between feet and $0.5 \mathrm{~m}$ between lines, i.e. 14 plants per elementary plot. Paths of $0.5 \mathrm{~m}$ have been observed between the elementary plots and the blocks. Soil field surveys were carried out on the horizon 0-20 $\mathrm{cm}$ deep, before and at the end of the experiment in order to assess the variation in soil fertility under each treatment. The treatments compared were:

- T0 : control without fertilizer (soil of the experimental site);

- T1: bio-waste at 1 month of decomposition, $3 \mathrm{t}$ / ha;

- T2: bio-waste at 3 months of decomposition, 3t / ha;

- T3: NPK (15-15-15), $200 \mathrm{~kg} / \mathrm{ha}$;

- T4: biofertilizer from the local market.

\section{Observations and Measures}

The observations and measurements related to: the width of the leaves, the number of leaves, the size of the roots and the height at the collar of the lettuce plants. These observations were made on 5 lettuces selected at random at each measurement on each elementary plot. The height was measured from the collar to the end of the root. The yield component determined was the total weight of the fresh mass of lettuce leaves, after digging up and rinsing the plants. To determine this component, the number and total weight of the fresh leaf mass of all crops in the elementary plots was added using an electronic balance. Physical soil analyzes of the grain size, porosity and salinity of the soil were determined. Chemical analyzes were also carried out on the soil samples. These are the $\mathrm{pH}$ which has been measured according to standardized methods (AFNOR NF ISO 10-390, 2005) and macroelements (N, P and $\mathrm{K}$ ), essential cations ( $\mathrm{Ca}$ and $\mathrm{Mg}$ ) and metallic trace elements ( $\mathrm{Pb}, \mathrm{Zn}, \mathrm{Mn}$ and $\mathrm{Fe}$ ). The Kjeldahl nitrogen content is determined in accordance with French standard AFNOR ISO 11-261. The contents of metallic elements (zinc, lead, manganese iron) and ionic species (calcium, sodium and potassium) are determined by flame atomic absorption spectrophotometry (SAA) after mineralization of the samples with aqua regia.

\section{Statistical Processing of the Data Collected}

The results of the observations and measurements were analyzed using SPSS version 20 software. An analysis of variance was first performed. Then, the means were separated by the TUKEY test at the threshold of $5 \%$ when the effects were significant. The normality of the data and the homogeneity of the variances were checked beforehand using the de, Kolmogorov-Smirnov and Shapiro-Wilk test, respectively.
RESULTS AND DISCUSSION

\section{Physico-Chemical Characteristics of the Organic Manure Used}

Table-1 reveals that the mineral content of biowaste increases significantly with decomposition time. Indeed, in the bio-waste at three months of decomposition the content of mineral elements such as $\mathrm{N}, \mathrm{C}, \mathrm{P}, \mathrm{K}, \mathrm{Ca}, \mathrm{Mg}$, Ir, Na, Mn, Ld, Zn is significantly more marked compared to the stage of a months of decomposition. The $\mathrm{C} / \mathrm{N}$ ratio is 12 for bio-waste at 3 months of decomposition, which indicates good mineralization of organic matter. As for bio-waste at 1 month of decomposition, the $\mathrm{C} / \mathrm{N}$ ratio is equal to 13 , which indicates slightly slow mineralization.

\section{Effect of treatments on soil parameters \\ Granulometry, porosity and salinity of the experimental site soil \\ The analysis results indicate that after} application of fertilizer and amendments, the clay content has significantly changed. Indeed, the control without intake had a clay content of $8.18 \mathrm{~g} / \mathrm{kg}$ but after the various treatments the clay content increased to $18.21 \mathrm{~g} / \mathrm{kg}$ for $\mathrm{T} 1 ; 18.10 \mathrm{~g} / \mathrm{kg}$ for T2; $18.8 \mathrm{~g} / \mathrm{kg}$ for $\mathrm{T} 3$ and $16.2 \mathrm{~g} / \mathrm{kg}$ for T4 treatment. As for the porosity, it is very low $(24.52 \%$ thus testifying to a compact soil for the witness. After application, the porosity under the various treatments increased to $54.70 \%$ for T1; $50.94 \%$ for $\mathrm{T} 2 ; 35.84 \%$ for $\mathrm{T} 3$ and finally $28.3 \%$ for $\mathrm{T} 4$. The porosity under treatment with bio-waste is highly significant compared to other treatments. The salinity of the soil has evolved in terms of $\mathrm{T} 1$ and $\mathrm{T} 2$ treatments; it is $0.05 \mathrm{mS} / \mathrm{cm}$ for $\mathrm{T} 1$ and $0.021 \mathrm{mS} / \mathrm{cm}$ for $\mathrm{T} 2$ against $0.02 \mathrm{mS} / \mathrm{cm}$ for the control T0. The salinity values at the level of T3 and T4 decreased compared to the control, ie $0.018 \mathrm{mS} / \mathrm{cm}$ for $\mathrm{T} 3$ and $0.013 \mathrm{mS} / \mathrm{cm}$ for T4. However, all these values remain at a level suitable for most plants (Table-2).

\section{Acidity, organic matter, nitrogen and assimilable phosphorus}

Examination of the results obtained after laboratory analyzes of the soil samples reveals a highly significant difference between the levels of organic matter (OM). The control soil had an OM content of $0.77 \mathrm{~g} / \mathrm{kg}$. After application of the various treatments the contents increased considerably. T1 and T2 treatments have contents of $12.8 \mathrm{~g} / \mathrm{kg}$ and $14.5 \mathrm{~g} / \mathrm{kg}$ respectively; at the level of $\mathrm{T} 3$ and $\mathrm{T} 4$, the values obtained are of the order of $9.74 \mathrm{~g} / \mathrm{kg}$ and $11 \mathrm{~g} / \mathrm{kg}$. Also, the nitrogen content improved considerably after the various applications. The soil $\mathrm{C} / \mathrm{N}$ ratio before application was 32.14, reflecting very slow mineralization of organic matter. The addition of fertilization and fertilization contributed to further lower this value, which fell to 6.05 for $\mathrm{T} 1 ; 7.21$ for $\mathrm{T} 2$; 9.13 and 8.3 for T3 and T4 showing moderately good mineralization at ground level (Table-3). 
Cationical exchange complex and exchangeable base The CEC values obtained after the different analyzes have a significant difference. The CEC before the treatments is low, ie $3.9 \mathrm{cmol}^{+} / \mathrm{kg}$. We note that after the treatments this value improved by passing to 8 $\mathrm{cmol}^{+} / \mathrm{kg}$ for T1, $8.1 \mathrm{cmol}^{+} / \mathrm{kg}$ for T2, $6.5 \mathrm{cmol}^{+} /$ $\mathrm{kg}$ for $\mathrm{T} 3$ and $7 \mathrm{cmol}^{+} / \mathrm{kg}$ for T4, i.e. double compared to the witness. With regard to calcium and magnesium, the values obtained before and after treatment are not significantly different. In terms of potassium, the values obtained are $0.32 \mathrm{cmol}^{+} / \mathrm{kg}$ for $\mathrm{T} 0,0.3 \mathrm{cmol}^{+} / \mathrm{kg}$ for
$\mathrm{T} 1,0.4 \mathrm{cmol}^{+} / \mathrm{kg}$ for T2 and T4, $0.44 \mathrm{cmol}^{+} / \mathrm{kg}$ for T3. At the calcium levels the values obtained are. 1.9 $\mathrm{cmol}^{+} / \mathrm{kg}$ for T0; $3.72 \mathrm{cmol}^{+} / \mathrm{kg}$ for T1; $3.3 \mathrm{cmol}^{+} /$ $\mathrm{kg}$ for $\mathrm{T} 2 ; 3.02 \mathrm{cmol}^{+} / \mathrm{kg} ; 3.2 \mathrm{cmol}^{+} / \mathrm{kg}$ respectively for T3 and T4. The sodium before treatment was 0.15 $\mathrm{cmol} / \mathrm{kg}$ in the soil. After application this value dropped considerably and went to $0.01 \mathrm{cmol} / \mathrm{kg}$ for $\mathrm{T} 1$. T2, T3 and T4 treatments helped increase the sodium level in the soil, ie 1.04 at T2, 0.84 at T3 and 1.41 at T4 (Table-4).

Table-1: Chemical composition of bio-waste at different stages of decomposition

\begin{tabular}{|c|c|c|c|c|c|c|c|c|c|c|c|c|c|}
\hline \multicolumn{12}{|c|}{ Parameters analyzed in $\mathrm{mg} . \mathrm{kg}^{-1}$} & $\begin{array}{l}\text { Mineralizati } \\
\text { on level }\end{array}$ & $\begin{array}{l}\text { Significan } \\
\text { ce }\end{array}$ \\
\hline $\begin{array}{l}\text { Manur } \\
\text { es }\end{array}$ & $\mathbf{N}$ & $\mathbf{C}$ & $\mathbf{P}$ & $\mathbf{K}$ & $\mathbf{C a}$ & Mg & Ir & $\mathbf{N a}$ & Mn & Ld & $\mathbf{Z n}$ & $\begin{array}{l}\text { (Repport } \\
\text { C/N) }\end{array}$ & \\
\hline $\begin{array}{l}1 \text { month } \\
\text { (T1) }\end{array}$ & $0.02 \mathrm{a}$ & $0.26 \mathrm{c}$ & $0.12 \mathrm{a}$ & $0.02 \mathrm{~d}$ & $0.02 \mathrm{c}$ & $0.03 \mathrm{a}$ & $5.33 b$ & $0.09 \mathrm{a}$ & $0.11 \mathrm{~b}$ & $0.06 \mathrm{a}$ & $0.06 \mathrm{c}$ & $13 \mathrm{a}$ & Slow \\
\hline $\begin{array}{l}3 \text { months } \\
\text { (T2) }\end{array}$ & $0.17 \mathrm{~b}$ & $2.04 \mathrm{a}$ & $0.96 \mathrm{c}$ & $0.17 \mathrm{c}$ & $0.19 \mathrm{~b}$ & $0.28 \mathrm{~b}$ & $\begin{array}{l}39.99 \\
\mathrm{c}\end{array}$ & $0.66 \mathrm{~b}$ & $0.81 \mathrm{c}$ & $0.47 \mathrm{~b}$ & $0.48 \mathrm{~b}$ & $12 \mathrm{~b}$ & Good \\
\hline F cal & 215.7 & 692.5 & $\begin{array}{l}294.2 \\
2\end{array}$ & 795.6 & $\begin{array}{l}120.9 \\
1\end{array}$ & $\begin{array}{l}564.8 \\
5 \\
\end{array}$ & $\begin{array}{l}419.2 \\
2\end{array}$ & $\begin{array}{l}531.0 \\
3\end{array}$ & $\begin{array}{l}668.6 \\
3 \\
\end{array}$ & $\begin{array}{l}335.6 \\
4 \\
\end{array}$ & $\begin{array}{l}104.6 \\
9\end{array}$ & 27.31 & \\
\hline Cal Pr & $\begin{array}{l}0.001 \\
2\end{array}$ & $\begin{array}{l}0.002 \\
3\end{array}$ & $\begin{array}{l}0.001 \\
1\end{array}$ & $\begin{array}{l}0.004 \\
3\end{array}$ & $\begin{array}{l}0.005 \\
5\end{array}$ & $\begin{array}{l}0.002 \\
4\end{array}$ & $\begin{array}{l}0.007 \\
6\end{array}$ & $\begin{array}{l}0.004 \\
7\end{array}$ & $\begin{array}{l}0.004 \\
8\end{array}$ & $\begin{array}{l}0.002 \\
1\end{array}$ & $\begin{array}{l}0.008 \\
8\end{array}$ & 0.045 & \\
\hline Th Pr & $\begin{array}{l}< \\
0.01\end{array}$ & $\begin{array}{l}< \\
0.01\end{array}$ & $\begin{array}{l}< \\
0.01\end{array}$ & $\begin{array}{l}< \\
0.01\end{array}$ & $\begin{array}{l}< \\
0.01\end{array}$ & $\begin{array}{l}< \\
0.01\end{array}$ & $\begin{array}{l}< \\
0.01\end{array}$ & $\begin{array}{l}< \\
0.01\end{array}$ & $\begin{array}{l}< \\
0.01\end{array}$ & $\begin{array}{l}< \\
0.01\end{array}$ & $\begin{array}{l}< \\
0.01\end{array}$ & $<0.05$ & \\
\hline
\end{tabular}

Legend : $\mathbf{N}$ : nitrogen , $\mathbf{C}$ : carbon, $\mathbf{P}:$ phosphorus, $\mathbf{K}:$ potassium, $\mathbf{C a}:$ calcium, $\mathbf{M g}:$ magnesium, $\mathbf{I r}:$ Iron, $\mathbf{N a}:$ sodium, Mn : manganese, Ld : lead, Zn : zinc. not significantly different at the Probability threshold $<0.05$, according to the TUKEY method, (F.cal $=$ File calculated, $\operatorname{Pr}$ cal $=$ Probability calculated, $\mathrm{Th} \operatorname{Pr}=$ Theoretical Probability). $\mathrm{T} 1=1$ month of decomposition, $\mathrm{T} 2=$ fertilization at 3 months of decomposition.

Table-2: Granulometry, porosity and salinity of the soil and treatments

\begin{tabular}{|c|c|c|c|c|c|c|c|c|c|}
\hline & \multicolumn{5}{|l|}{ Treatments } & \multirow{2}{*}{$\begin{array}{l}\text { Associated } \\
\text { statistical } \\
\text { tests }\end{array}$} & \multirow[t]{2}{*}{$P$ cal } & \multirow{2}{*}{ Significance } \\
\hline & & T0 & T1 & T2 & T3 & T4 & & & \\
\hline \multirow{5}{*}{$\begin{array}{l}\text { Granulometry } \\
(\mathrm{g} / \mathrm{kg})\end{array}$} & $\mathrm{A}$ & $8.18 \pm 0 \mathrm{a}$ & $18.21 \pm 0 \mathrm{~b}$ & $18.10 \pm 0 \mathrm{~b}$ & $18.8 \pm 0 \mathrm{~b}$ & $16.2 \pm 0 \mathrm{~b}$ & $\mathrm{~F}=$ & 0.00 & *** \\
\hline & Lf & $16.27 \pm 1.01 \mathrm{a}$ & $15.3 \pm 1.03 \mathrm{a}$ & $15.21 \pm 1.01 \mathrm{a}$ & $16.5 \pm 1.1 \mathrm{a}$ & $13.3 \pm 0 \mathrm{a}$ & $\chi^{2}=$ & 0.2 & ns \\
\hline & $\mathrm{Lg}$ & $19.15 \pm 0 \mathrm{a}$ & $20.4 \pm 1.01 \mathrm{a}$ & $22.41 \pm 0.11 \mathrm{a}$ & $21.35 \pm 0.01 \mathrm{a}$ & $20.1 \pm 1.1 \mathrm{a}$ & $\chi^{2}=$ & 0.20 & ns \\
\hline & Sf & $26.23 \pm 0 \mathrm{a}$ & $19.05 \pm 0 \mathrm{~b}$ & $21.05 \pm 0 \mathrm{~b}$ & $26.18 \pm 0 \mathrm{~b}$ & $20.37 \pm 0 \mathrm{~b}$ & $\mathrm{~F}=$ & 0.026 & $* *$ \\
\hline & $\mathrm{Sg}$ & $30.17 \pm 0.1 \mathrm{a}$ & $23.05 \pm 0.01 \mathrm{a}$ & $23.23 \pm 0.11 \mathrm{a}$ & $17.17 \pm 0.1 \mathrm{a}$ & $22.63 \pm 0 a$ & $\chi^{2}=$ & 0.2 & ns \\
\hline Porosity (\%) & Por & $24.52 \pm 8.8 \mathrm{a}$ & $54.70 \pm 6.65 b$ & $50.94 \pm 2.51 \mathrm{~b}$ & $35.84 \pm 7.94 \mathrm{~b}$ & $28.30 \pm 8.8 \mathrm{a}$ & $\mathrm{F}=$ & 0.00 & ** \\
\hline Salinity & Sal & $0.02 \pm 0.2 \mathrm{a}$ & $0.05 \pm 0.15 b$ & $0.021 \pm 0.92 \mathrm{a}$ & $0.018 \pm 0.008 \mathrm{a}$ & $0.013 \pm 0.012 \mathrm{a}$ & $\mathrm{F}=$ & 0.00 & $* *$ \\
\hline
\end{tabular}

The means followed by the same letter, on the same line, are not significantly different at the Probability threshold $<0.05$, according to the TUKEY method, AST $=$ applied statistical test: $\chi^{2}=$ which two from Kruskal Walis, F $=$ F of File, Cal pr $=$ Calculated probability, $\mathrm{Th} \mathrm{Pr}=$ Theoretical probability). $\mathrm{T} 1=1$ month of decomposition, $\mathrm{T} 2=$ fertilization at 3 months of decomposition. $* *=$ significant, $\mathrm{ns}=$ not significant; $\mathrm{c}=$ clay; $\mathrm{fs}=$ fine silt; $\mathrm{cs}=$ coarse silt; fs fine sand; $\mathrm{cs}=$ coarse sand.

Table-3: Acidity, organic matter, nitrogen and assimilable phosphorus of the control soil and treatments

\begin{tabular}{|c|c|c|c|c|c|c|c|c|c|}
\hline \multirow[t]{2}{*}{ Parameters analyzed } & \multicolumn{5}{|c|}{ Treatments } & \multirow{2}{*}{$\begin{array}{l}\text { Associated } \\
\text { statistical } \\
\text { tests }\end{array}$} & \multirow{2}{*}{$\begin{array}{l}\mathbf{P} \\
\text { cal }\end{array}$} & \multirow{2}{*}{\multicolumn{2}{|c|}{ Significance }} \\
\hline & T0 & T1 & T2 & T3 & T4 & & & & \\
\hline Acidity & $\mathrm{pH}$ & $5.4 \pm 0.13 \mathrm{~b}$ & $7.2 \pm 0.13 \mathrm{a}$ & $6.1 \pm 0.1 \mathrm{ab}$ & $6.2 \pm 0.16 \mathrm{ab}$ & $6.7 \pm 0.13 \mathrm{a}$ & $\chi^{2}=$ & 0.2 & ns \\
\hline Carbon $(\mathrm{g} / \mathrm{kg})$ & $\mathrm{C}$ & $0.45 \pm 0.01 \mathrm{a}$ & $7.44 \pm 0 \mathrm{~b}$ & $8.43 \pm 0 \mathrm{~b}$ & $5.66 \pm 0 \mathrm{~b}$ & $9.3 \pm 0.01 \mathrm{~b}$ & $\mathrm{~F}=$ & 0.024 & *** \\
\hline Organical matter $(\mathrm{g} / \mathrm{kg})$ & $\mathrm{OM}$ & $0.77 \pm 0.11 \mathrm{a}$ & $12.8 \pm 1.5 \mathrm{~b}$ & $14.5 \pm 0.92 \mathrm{~b}$ & $9.74 \pm 0.98 \mathrm{~b}$ & $11 \pm 1.5 \mathrm{~b}$ & $\mathrm{~F}=$ & 0.022 & $* *$ \\
\hline Nitrogen $(\mathrm{g} / \mathrm{kg})$ & $\mathrm{N}$ & $0.01 \pm 0 \mathrm{a}$ & $1.23 \pm 0.01 \mathrm{~b}$ & $1.17 \pm 0 \mathrm{~b}$ & $0.62 \pm 0.01 \mathrm{~b}$ & $1.12 \pm 0 \mathrm{~b}$ & $\mathrm{~F}=$ & 0.027 & *** \\
\hline Carbon/Nitrogen ratio & $\mathrm{C} / \mathrm{N}$ & $32.14 \pm 3.36 \mathrm{a}$ & $6.05 \pm 0.12 b$ & $7.21 \pm 0.1 \mathrm{~b}$ & $9.13 \pm 0.15 b$ & $8.3 \pm 0.12 \mathrm{~b}$ & $\mathrm{~F}=$ & 0.00 & *** \\
\hline Assimilable phosphorus (mg/kg) & $\mathrm{P}_{2} \mathrm{O}_{5}$ & $41.37 \pm 0 \mathrm{a}$ & $70.04 \pm 0 \mathrm{~b}$ & $62.32 \pm 0 \mathrm{~b}$ & $65.57 \pm 0 \mathrm{~b}$ & $62.7 \pm 0 \mathrm{~b}$ & $\mathrm{~F}=$ & 0.01 & *** \\
\hline
\end{tabular}

The means followed by the same letter, on the same line, are not significantly different at the Probability threshold $<0.01$, according to the TUKEY method, AST $=$ applied statistical test: $\chi^{2}=$ which two Kruskal Walis test, $\mathrm{F}=\mathrm{F}$ of File $($ anova $)$, cal Pr $=$ Calculated probability, T1 $=1$ month of decomposition, $\mathrm{T} 2=$ fertilization at 3 months of decomposition. $* *=$ significant, ns $=$ not significant. 
Table-4: Cationic exchange complex and exchangeable base.

\begin{tabular}{|c|c|c|c|c|c|c|c|c|c|}
\hline \multirow{2}{*}{\multicolumn{2}{|c|}{$\begin{array}{l}\text { Parameters of the soil analyzed } \\
\left(\mathrm{cmol}^{+} / \mathrm{kg}\right)\end{array}$}} & \multicolumn{5}{|l|}{ Treatments } & \multirow{2}{*}{$\begin{array}{l}\text { Associated } \\
\text { statistical } \\
\text { tests (AST) }\end{array}$} & \multirow[t]{2}{*}{ P cal } & \multirow[t]{2}{*}{ Significance } \\
\hline & & T0 & T1 & T2 & T3 & T4 & & & \\
\hline Cationic exchange capacity & CEC & $3.9 \pm 0.34 \mathrm{~b}$ & $8 \pm 0.3 b$ & $8.1 \pm 0.3 b$ & $6.5 \pm 0.34 b$ & $7 \pm 0.31 b$ & $\chi^{2}=$ & 0.08 & ns \\
\hline Calcium & $\mathrm{Ca}^{2+}$ & $1.9 \pm 0.02 \mathrm{a}$ & $3.72 \pm 0.1 \mathrm{~b}$ & $3.3 \pm 0.04 b$ & $3.02 \pm 0.05 \mathrm{~b}$ & $3.2 \pm 0.1 \mathrm{~b}$ & $\mathrm{~F}=$ & 0.008 & $* *$ \\
\hline Magnesium & $\mathrm{Mg}^{2+}$ & $0.4 \pm 0.1 \mathrm{~b}$ & $0.8 \pm 0.11 \mathrm{~b}$ & $0.94 \pm 0.1 b$ & $0.93 \pm 0.2 \mathrm{~b}$ & $0.7 \pm 0.1 \mathrm{~b}$ & $\chi^{2}=$ & 0.2 & ns \\
\hline Potassium & $\mathrm{K}^{+}$ & $0.32 \pm 0.01 \mathrm{a}$ & $0.3 \pm 0.01 \mathrm{a}$ & $0.4 \pm 0.01 \mathrm{a}$ & $0.44 \pm 0 \mathrm{a}$ & $0.4 \pm 0 \mathrm{a}$ & $\chi^{2}=$ & 0.2 & $\mathrm{~ns}$ \\
\hline Sodium & $\mathrm{Na}^{+}$ & $0.15 \pm 0.11 \mathrm{a}$ & $0.01 \pm 0.11 \mathrm{a}$ & $1.04 \pm 0.11 \mathrm{a}$ & $0.84 \pm 0.1 \mathrm{a}$ & $1.41 \pm 0.1 \mathrm{a}$ & $\chi^{2}=$ & 0.174 & $\mathrm{~ns}$ \\
\hline
\end{tabular}

The means followed by the same letter, on the same line, are not significantly different at the Probability threshold $<0.01$, according to the TUKEY method, AST $=$ applied statistical test: $\chi^{2}=$ which two Kruskal Walis test, $\mathrm{F}=\mathrm{F}$ of File (anova), cal $\mathrm{Pr}=$ Calculated probability, $\mathrm{T} 1=1$ month of decomposition, $\mathrm{T} 2=$ fertilization at 3 months of decomposition. $* *=$ significant, $\mathrm{ns}=$ not significant.

\section{Effect of treatments on the agronomic parameters measured at the lettuce level \\ Number of leaves}

The various organic and fertilizing amendments had very significant effects on the number of leaves of lettuce plants. The greatest number of leaves was observed with the seed cotton treatment at 1 month of decomposition (T1) with an average number of 45 leaves per plant. Furthermore, the T3 and T4 treatment respectively have an average number of 23 leaves and 18 leaves per plant, on the other hand the NPK treatments and the control have the same average number of leaves, ie 21 leaves per plant. The analysis of variance (ANOVA 1) and the Tukey test applied to the data confirm that the $\mathrm{T} 1$ treatment has the significantly higher number of leaves (Table-5).

\section{Height of Plants}

The different treatments carried out had significant effects on the height at the root of the lettuce plants. The greatest height was recorded in the seed cotton treatment at 1 month of decomposition with an average plant height of $16.2 \mathrm{~cm}$. The treatments based on seed cotton at 3 months of decomposition, the NPK, the organic fertilizer and the control recorded average heights of $13.6 \mathrm{~cm}, 10.6 \mathrm{~cm}, 12.3 \mathrm{~cm}$ and $8.8 \mathrm{~cm}$ respectively. The Kruskal Walis test applied confirms that the $\mathrm{T} 1$ treatment presented significantly higher plant heights (Table-5).

\section{Root Size}

The treatments had a significant impact on the size of the roots. The T1 treatment has a highly significant difference compared to other treatments with an average root size of $22.5 \mathrm{~cm}$. Treatments T0, T2, T3 and T4 have a root size of $14 \mathrm{~cm}, 15 \mathrm{~cm}, 16.15 \mathrm{~cm}$ and $15 \mathrm{~cm}$ respectively. The variance analysis (KrusKalWalis) and the post ANOVA test confirm that the largest root size is recorded at T1 level (Table-5).

\section{Root Width}

Descriptive statistical analysis shows that the different organic fertilizer and fertilizer treatments had a significant effect on the leaves width. The analysis of variance and the TUKEY test applied to the data shows a very highly significant difference for the $\mathrm{T} 1$ treatment which records the largest leaves width $(21.4 \mathrm{~cm})$. Treatments T3 and T4 have leaves width of $12.6 \mathrm{~cm}$ and $12.2 \mathrm{~cm}$ respectively. T0 and T2 have a width relatively below and respectively $12.1 \mathrm{~cm}$ and $12.6 \mathrm{~cm}$, Pcal $=0.000($ Table-5)

\section{Productivities}

Table-5 presents the effect of the different treatments performed on the yield of lettuces produced. Analysis of the results in this table shows that T1 significantly contributed to the increase in lettuce yield compared to the control (T0), treatments, T2, T3 and T4. The yields are in the proportions of $1.39 \mathrm{t} /$ ha for (T1) against $0.57 \mathrm{t} /$ ha for (T2), $0.23 \mathrm{t} / \mathrm{ha}, 0.4 \mathrm{t} / \mathrm{ha}$, and $0.23 \mathrm{t} /$ ha respectively for $\mathrm{T} 0, \mathrm{~T} 3, \mathrm{~T} 4$. The analysis of variance and the Tukey test shows that the performance at $\mathrm{T} 1$ level is significantly different compared to other treatments.

Table-5: Agronomic parameters from the different treatments

\begin{tabular}{|l|l|l|l|l|l|l|l|l|l|}
\hline $\begin{array}{l}\text { Agronomic } \\
\text { analyzed }\end{array}$ & parameters & Treatments & T1 & T2 & T3 & T4 & $\begin{array}{l}\text { Associated } \\
\text { statistical } \\
\text { tests (AST) }\end{array}$ & P cal & Significance \\
\cline { 3 - 10 } & T0 & & & & & \\
\hline Leaf number & LN & $19 \pm 1,53 \mathrm{a}$ & $43 \pm 2,65 \mathrm{~b}$ & $21 \pm 2,52 \mathrm{a}$ & $21 \pm 2,65 \mathrm{a}$ & $19 \pm 2,65 \mathrm{a}$ & $\mathrm{F}=$ & 0,00 & $* *$ \\
\hline Plants height & $\mathrm{PH}$ & $8,5 \pm 0,15 \mathrm{a}$ & $15,19 \pm 0,26 \mathrm{~b}$ & $13,3 \pm 0,31 \mathrm{c}$ & $10,2 \pm 0,26 \mathrm{~d}$ & $12 \pm 0,21 \mathrm{e}$ & $\chi^{2}=$ & 0,009 & $* *$ \\
\hline Size root & SR & $14,33 \pm 1,53 \mathrm{a}$ & $22,5 \pm 0,26 \mathrm{a}$ & $13,3 \pm 3,21 \mathrm{a}$ & $16,15 \pm 0,3 \mathrm{a}$ & $13,3 \pm 3,21 \mathrm{a}$ & $\chi^{2}=$ & 0,08 & $\mathrm{~ns}$ \\
\hline Leaves width & $\mathrm{LW}$ & $12,67 \pm 1,53 \mathrm{ab}$ & $21,47 \pm 0,32 \mathrm{c}$ & $15 \pm 2,65 \mathrm{~b}$ & $12,6 \pm 0,26 \mathrm{ab}$ & $12,1 \pm 0,26 \mathrm{a}$ & $\mathrm{F}=$ & 0,00 & $* *$ \\
\hline Productivity (t/ha) & $\mathrm{P}$ & $0,23 \pm 0 \mathrm{a}$ & $1,39 \pm 0,01 \mathrm{~b}$ & $0,57 \pm 0,01 \mathrm{c}$ & $0,4 \pm 0,01 \mathrm{~d}$ & $0,23 \pm 0 \mathrm{a}$ & $\mathrm{F}=$ & 0,00 & $* *$ \\
\hline
\end{tabular}

The means followed by the same letter, on the same line, are not significantly different at the Probability threshold $<0.01$, according to the TUKEY method, (STA = statistical treatment applied: $\mathrm{F}=\mathrm{F}$ of File (anova); $\chi^{2}$ (Kruskal Walis test), Cal Pr $=$ Calculated probability, T1 $=1$ month of decomposition, T2 = manure at 3 months of decomposition, T3: NPK, T4: fertilizer from the local market. $* *=$ significant; $\mathrm{ns}=$ not significant 


\section{DISCUSSION}

Before the cultures were put in place and the various treatments applied, the study site had a low porosity of around $24.52 \%$. This soil was poor in organic matter, carbon and nitrogen. It contained $0.77 \mathrm{~g}$ / kg of organic matter, $0.01 \mathrm{~g} / \mathrm{kg}$ of nitrogen and $0.45 \mathrm{~g}$ / $\mathrm{kg}$ of carbon. The $\mathrm{C} / \mathrm{N}$ ratio was 32.14 , which indicates very slow mineralization of organic matter in this soil. The cationic exchange capacity is $3.9 \mathrm{cmol} /$ $\mathrm{kg}$, which indicates a low capacity of the soil to retain on its surface the ions necessary for plant nutrition. These characteristics are typical of degraded soils. The north of Cote d'Tvoire is no exception to this phenomenon. It tends to be accentuated in the department of Korhogo. This is certainly due to overgrazing and cultivation, which have greatly contributed to reducing the plant cover as well as the rate of organic matter, thus promoting soil compaction [10].

The aim of this work being the restoration of degraded soils, the application of organic manures based on seed cotton, allowed us to improve the soil fertility of the experimental site.

Laboratory analyzes indicated an improvement in the physical, physico-chemical and chemical properties of the soil. Indeed, the organic matter content (OM) which was $0.77 \mathrm{~g} / \mathrm{kg}$ rose to $12.8 \mathrm{~g} / \mathrm{kg}$ at the level of $\mathrm{T} 1,14.5 \mathrm{~g} / \mathrm{kg}$ at the level of $\mathrm{T} 2 ; 9.74 \mathrm{~g} / \mathrm{kg}$ at T3 level and $11 \mathrm{~g} / \mathrm{kg}$ at T4 level. The nitrogen $(\mathrm{N})$ content has increased considerably. It went from $1.23 \mathrm{~g}$ / $\mathrm{kg}$ for $\mathrm{T} 1,1.17 \mathrm{~g} / \mathrm{kg}$ for $\mathrm{T} 2,0.26 \mathrm{~g} / \mathrm{kg}$ and $1.12 \mathrm{~g} /$ $\mathrm{kg}$ at the level of T3 and T4 compared to T0 $(0.01 \mathrm{~g} /$ $\mathrm{kg}$ ). The $\mathrm{C} / \mathrm{N}$ ratio which characterizes the state of mineralization of organic matter at the control level is 32.14 (very slow mineralization).

After applying the different treatments, the C / $\mathrm{N}$ ratio at the treatment level has improved significantly. This ratio at $\mathrm{T} 1$ level is $6.05 ; 7.21$ at $\mathrm{T} 2$, 9.13 and 8.3 at T3 and T4. Although the values obtained at the level of $\mathrm{T} 1$ and $\mathrm{T} 2$ are below 8, they tend to have good mineralization. The results of the application of organic manure based on seed cotton indicates the beginning of restoration of this degraded soil. Indeed, if the $\mathrm{C} / \mathrm{N}$ ratio obtained is less than 8 , the degradation of the organic matter is excessive. The soil is unable to maintain the decreasing microbial mass due to the lack of carbon. When in a given soil the $\mathrm{C} / \mathrm{N}$ ratio is between 8 and 12, the organic matter evolves correctly a priori, while if the $\mathrm{C} / \mathrm{N}$ ratio is greater than 12 , the evolution of the organic matter is slowed down due to the inability of the soil microflora to multiply (lack of nitrogen).

The consequence of a good evolution of the organic matter is that the humus, flocculating with the clay forms the clay-humic complex, true reserve and nourishing base of the earth. The formation and accumulation of humus allows the storage of most of the elements $(\mathrm{C}, \mathrm{O}, \mathrm{H}, \mathrm{N}, \mathrm{P}, \mathrm{K}, \mathrm{S}$, trace elements) essential to life [11]. All microbiology (bacteria, fungi ...) and soil fauna (earthworms, termites ...) participate in its formation. Its degradation contributes to the release of $\mathrm{CO}^{2}$, while its development fixing the carbon fights against the greenhouse effect [11]. It "protects" the clay and stabilizes the soil structure. Humic compounds, by binding to clay, help to improve the porosity of the soil. This porosity, which was $24.52 \%$ before the treatments, rose to $51.57 \%$ for $\mathrm{T} 1,55.34 \%$ for $\mathrm{T} 2,35.84 \%$ for $\mathrm{T} 3$ and $28.3 \%$ for $\mathrm{T} 4$. The soil is thus more aerated, less subject to compaction, leaching and erosion by rain and watering, and it stores water better; all of which make it more fertile.

In addition, the structural role of humus induces a good penetration of the soil by the air and therefore the oxygenation in depth allowing to stimulate a good biological activity of the macro and micro-fauna and flora of the soil [12]. The roots penetrate more easily in depth; which contributes to improving their exploration of the soil and subsoil and therefore their supply of water and minerals. This explains the relatively good size of the roots at the level of the T1 and T2 treatments which are $22.5 \mathrm{~cm}$ and $15 \mathrm{~cm}$ compared to the control (T0) which is $14 \mathrm{~cm}$.

The manures made from seed cotton had very significant effects on the yield of lettuce. The highest production of lettuce is observed with seed cotton at 1 month and 3 months of decomposition of $1.39 \mathrm{~T} / \mathrm{ha}$ and $0.57 \mathrm{~T} /$ ha respectively; NPK and biofertilizer treatments produced respective yields of $0.4 \mathrm{~T} / \mathrm{ha}$ and $0.23 \mathrm{~T} / \mathrm{ha}$. The richness of seed cotton in nitrogen confirms the results cited above, hence the high yield recorded compared to NPK and organic fertilizer. The highest average number of leaves per plant was recorded in seed cotton at 1 month of decomposition, i.e. an average number of 45 leaves per plant, followed by seed cotton at 3 months of decomposition (23 leaves / plant), NPK (21 leaves / plant, control (21 leaves / plant and organic fertilizer (18 leaves / plant). The richness of manures made from seed cotton in nitrogen, organic matter, phosphorus, had a positive effect on the average number of leaves. Nitrogen is the key element in plant nutrition, it is involved in the synthesis of proteins, chlorophyll and other major compounds determining in plant metabolism. involved in the growth and development process of crops. Phosphorus promotes root development and is involved in maturation, the mobilization of nutrient reserves and the transmission of hereditary characteristics. an activator of several enzymes such as: Acetic Thiokinase, Aldolase, Pyruvate kinase and ATPase and promotes the synthesis of carbohydrates and amino acids. This corroborates with the observations made by certain authors [13] after using the compost enriched with poultry manure for the production of cabbage on sandy soil. Similar results have been reported by certain 
authors [14] after using compost enriched with poultry manure for the production of lettuce on ferrallitic soil. Nitrogen is a constituent element of chlorophyll, it is a determining factor in the growth and the determination of the yield of plants [15]. The positive effects of biowaste based on seed cotton at 1 month of decomposition appeared more explicitly on the development of the root system with a root size of 22.5 $\mathrm{cm}$. Unlike the bio-waste based on seed cotton at 3 months of decomposition which is $15 \mathrm{~cm}$, the NPK (15$15-15)$ which is $16.15 \mathrm{~cm}$ and the organic fertilizer which is $15 \mathrm{~cm}$. As for the witness, he developed a root size of $14 \mathrm{~cm}$. The widths of the largest leaves are recorded at the level of the bio-waste based on seed cotton at 1 month of decomposition, with $21.47 \mathrm{~cm}$, while T2, T3, T4 and T0 presented $15 \mathrm{~cm}, 12.6 \mathrm{~cm}$, $12.1 \mathrm{~cm}$ and $12.67 \mathrm{~cm}$, respectively. The improved yield in terms of seed cotton treatments can also be explained by the fact that inside organic matter, aluminum ion is complexed in particular by humic and fulvic acids. Organic matter reduces toxicities by complexing ions, therefore aluminum [15].

\section{CONCLUSION}

The work presented made it possible to identify the chemical characteristics of bio-waste which improve the agronomic parameters of cultivated plants even under degraded soil. The study showed that the contribution of biowaste from seed cotton at 1 month and 3 months of decomposition had improved soil fertility and therefore the yield of lettuce. The highest yields are recorded at the level of treatments based on bio-waste at 1 month and 3 months of decomposition, respectively $1.39 \mathrm{~T} / \mathrm{ha}$ and $0.57 \mathrm{~T} / \mathrm{ha}$, against $0.4 \mathrm{~T} /$ ha for NPK, and 0, 23T / ha for organic fertilizer and control soil. This was very marked on the root system of the lettuce, the number of leaves, the width of the leaves and on the height at the collar of the lettuce plants. NPK and the biofertilizer did not significantly influence the yield of lettuce. The contribution of seed cotton to a decomposition 1 to help lower the $\mathrm{Na}^{+}$level, and to raise the rate of, $\mathrm{N}, \mathrm{OM}, \mathrm{P}_{2} \mathrm{O}_{5}$ and $\mathrm{K}^{+}$. However, in view of the results obtained, bio-waste based on seed cotton at 1 month and 3 months of decomposition could be recommended to producers for the cultivation of lettuce at a dose of $0.012 \mathrm{t} / \mathrm{ha}$. But for an efficiency of the organic amendment, we can suggest fractional contributions to avoid the losses of nutrients by leaching. Given these encouraging initial results, it would be envisaged to define standard characteristics of bio-waste and test more drastic reductions in water regime and more in line with the reality on the ground.

\section{REFERENCES}

1. Yoni M, Hien V, Abbadie L, Serpentié G. Dynamique de la matière organique du sol dans les savanes soudaniennes du Burkina Faso. Cahiers d'Agriculture. 2005;14(6): 525-532.

2. Saïdou A, Bachabi SFX, Padonou GE, Biaou ODB, Balogoun I, Kossou D. Effet de l'apport d'engrais organiques sur les propriétés chimiques d'un sol ferralitique et la production de laitue au Sud Bénin. Revue CAMES-Série A. 2012;13(2): 281-285.

3. Koné B, Diatta S, Saïdou A, Akintayo I, Cissé B. Réponses des variétés interspécifiques du riz de plateau aux applications de phosphate en zone de forêt au Nigeria. Canadian Journal of Soil Science. 2009; 89(5): 555-565.

4. Duru M, Therond O, Martin G, Martin-Clouaire R, Magne MA, Justes E, Journet EP, Aubertot JN, Savary S, Bergez JE, Sarthou JP. Challenges of implementing biodiversity-based agriculture to enhance ecosystem services. A review. Agronomy for Sustainable Development. 2015; 35: 1259 . 1281.

5. Malézieux E, Crozat Y, Dupraz C, Laurans M, Makowski D, Ozier LH, Rapidel B, De Tourdonnet S, Valantin-Morison M. Mixing plant species in cropping systems: concepts, tools and models. A review. Agronomy for Sustainable Development. 2009;29(1):43-62.

6. Weber J, Karczewska A, Drozd J, Lieznar M, Lieznar S, Jamroz E, Kocowiez A. Agricultural and ecological aspects of sandy soil as affected by the application of municipal solid waste composts. Soil Biology and Biochemistry. 2007;39: 12941302.

7. Cardinael R, Guenet B, Chevallier T, Dupraz C, Cozzi T, Chenu C. High organic inputs explain shallow and deep SOC storage in a long-term. Agroforestry system-combining experimental and modeling approaches Biogeosciences. 2018;15: 297-317.

8. Tognetti C, Mazzarino MJ, Laos F. Compost of municipal organic waste: effects of different management pratrices on degrability and nutrient release capacity. Soil Biology Biotechnology. 2008; 49: 2290-2296.

9. Yao TB, Jean-Louis C. Visions paysannes et changements environnementaux en Côte d'Ivoire / Peasant visions of environmental in Ivory Coast. Annales de Géographie, 2007: 65-87.

10. N'Guessan K, Diarrassouba N, Alui KA, Fofana IJ, Yao-kouamé A. Indicateurs de dégradation physique des sols dans le nord de la Côte d'Ivoire: cas de Boundiali et Ferkessédougou. Afrique Sciences, 2015; 11(3): 115-128.

11. Ben Hassine H, Karbout N, Kridan K, Sanaa M, Jedidi N. Caractérisation des fractions colloïdales minérales et organiques des horizons superficiels des sols d'une toposéquence en zone semi-aride de la Tunisie. Etude et Gestion des Sols, 2012; $19: 14$

12. Le Villo M, Arrouays D, Deslais W, Daroussin J, Le Bissonais Y, Clergeot D. Estimation des quantités de matière organique exogène nécessaires pour restaurer et entretenir les sols limoneux français à un niveau organique donné. Etude et Gestion des Sols, 2001; 8(1): 47-63. 
13. Amadji GL, Saïdou A, Chitou L. Recycling of residues in compost to improve coastal sandy soil properties and cabbage shoot yield in Bénin. International Journal of Biological and Chemical Sciences, 2009; (2):192-202.

14. Saidou A, Bachabi SFX, Padonou GE., Biaou ODB, Balogoun I, Kossou D. Effect of organic manure on the chemical properties of a ferralitic soil and lettuce production in southern Benin. Revue CAMES-Série A, 2012: 13(2): 281-285.

15. Biaou ODB, Saidou A, Bachabi FX, Padonou GE, Balogoun I. Effet de l'apport de différents types d'engrais organiques sur la fertilité du sol et la production de la carotte (Daucus carota L.) sur sol ferralitique au sud Bénin. 2017 ;11(5):2315-2326. 